\title{
AC 2007-2139: GIFTED STUDENTS' PERCEPTIONS OF ENGINEERS ? A STUDY OF STUDENTS IN A SUMMER OUTREACH PROGRAM
}

\section{Euridice Oware, Purdue University}

Euridice Oware is a Ph.D. student in the Department of Engineering Education at Purdue University. She received her B.S. in Civil Engineering from Washington University and M.S. in Civil Engineering with an emphasis in structures and transportation from Purdue University.

\section{Brenda Capobianco, Purdue University}

Dr. Brenda Capobianco is an Assistant Professor in Science Education in the Department of Curriculum and Instruction and Affiliated Faculty in Women's Studies at Purdue University.

\section{Heidi Diefes-Dux, Purdue University}

Heidi Diefes-Dux is an Associate Professor in the Department of Engineering Education (ENE) at Purdue University with a joint appointment in the Department of Agricultural and Biological Engineering (ABE). She is the chair of the ENE Graduate Committee and she is a member of the Teaching Academy at Purdue. She received her B.S. and M.S. in Food Science from Cornell University and her Ph.D. from ABE in 1997. Her research interests include open-ended problem solving, evaluation of education technology, and first-year and graduate curriculum development. 


\title{
Gifted Students' Perceptions of Engineers - A Study of Students in a Summer Outreach Program
}

\begin{abstract}
The Gifted Education Resource Institute (GERI) at Purdue University holds several summer outreach classes for gifted elementary and secondary school students. The program gives students access to challenging science, mathematics, computer, and humanities classes. The purpose of this study is to investigate 3rd and 4th grade GERI students' perceptions of engineers for students enrolled in various Summer 2006 classes. This qualitative study was conducted using a constructivist theoretical framework. Eighteen students completed a background questionnaire, drew an engineer doing engineering work, and discussed engineering in an individual interview. Data analysis was conducted using content analysis, which included axial coding and categorizing data presented in student drawings, interviews, and questionnaires. Results show that students held common misconceptions about engineers while others were knowledgeable about what engineers do. Data also revealed sources of students' knowledge about engineering, including personal experiences with engineers, as key factors that contribute to their current conceptions. This study provides insight on children's perceptions about engineers and provides implications for developing engineering education curriculum at the elementary school level.
\end{abstract}

\section{Introduction}

Engineering is key to developing and improving scientific and technological products and services that maintain and improve the lives of people in society. According to the National Academies' Rising Above the Gathering Storm report, sustained expertise in science and engineering are fundamental to maintaining American's high standard of living and the economy - yet "the scientific and technological building blocks critical to our economic leadership are eroding at a time when many other nations are gathering strength." 1 Some warn that there is a gap between the needed number of scientists, engineers, and other technical professionals and the actual production of these professionals. ${ }^{2}$ Also, employment growth of the science and engineering workforce will slow if trends such as retirement and degree trends continue. ${ }^{3}$

Misconceptions and stereotypes about engineering within the American culture make it more difficult to attract students to engineering. Students in U.S. elementary and secondary classrooms often have not been exposed to engineering which may in turn contribute to the development of engineering misconceptions. ${ }^{4}$ Many people do not understand the breadth of opportunities available in engineering. For example, certain engineering fields are not very wellknown, such as materials engineering and industrial engineering. ${ }^{5}$ When students actually do hear about engineering, they are often presented with information that does not exhibit engineering in a positive manner. Some K-12 students are discouraged from becoming engineers due to a fear of math, belief that there is too much work involved in engineering, the stereotype that engineers are all nerds, or lack of knowledge about what engineers actually do. A lack of understanding about engineering leads to students entering postsecondary education being unable 
to make well-informed decisions about their majors; many students either select other majors or leave science and engineering for other majors. ${ }^{6,7}$

Research on children's perceptions of engineers is needed to inform researchers about children's understandings of engineering in various settings. Recent studies about children and their conceptions of engineers have used children's drawings to reveal their ideas about engineering. ${ }^{8}$, 9,10,11 For example, researchers at the University of South Carolina used a "Draw-an-Engineer" instrument and semi-structured interview in pre- and post-tests of 3rd -5th grade students in a classroom with an engineering graduate student visiting instructor. The researchers found that students generally presented fewer "misconceptions" of engineering on post-assessments than pre-assessment drawings and interviews. Researchers at the Museum of Science in Boston and Tufts University developed a Draw an Engineer Test for students from grades 3-12. The drawn responses included images such as tools, cars, computers, trains, and desks. Drawings and interviews enable students to communicate their ideas about engineers.

This research extends the use of children's drawings and interviews by studying a distinct population of children enrolled in a Gifted Education Resource Institute (GERI) outreach program at Purdue University, a research-intensive university in West Lafayette, IN. Unique to this study is emphasis on children's perceptions for students engaged in a series of educationally challenging STEM outreach programs geared toward enhancing children's understandings of several professions. Participants include students enrolled in various classes, including two engineering classes. The purpose of this research is to examine 3rd and 4th grade students' perceptions of engineers for students enrolled in the GERI Summer 2006 program. The research questions are: What are $3^{\text {rd }}$ and $4^{\text {th }}$ grade GERI students' perceptions of engineers? How have $3^{\text {rd }}$ and $4^{\text {th }}$ grade GERI students learned about engineering? Do $3^{\text {rd }}$ and $4^{\text {th }}$ grade GERI students express interest in becoming an engineer one day?

\section{Setting and Participants}

Setting. The GERI program is based in the Purdue University Department of Educational Studies in the College of Education. GERI was founded in 1974 and has a mission to "promote the holistic development of talented P-16 students." 12 Students applying to the program in Summer 2006 were required to demonstrate "giftedness" via high scores on standardized tests, participation in their school's gifted program, or a teacher or parent recommendation. The Super Summer Programs include a Super Summer (nonresidential) program for P-4th grade students and a Summer Residential Program for students in grades 5-12. ${ }^{12}$ GERI courses are taught by instructors, predominantly graduate and undergraduate students, who develop curriculum, design lesson plans, and teach the courses.

Participants. Participants in this study are $3^{\text {rd }}$ and $4^{\text {th }}$ grade students in the week-long Summer Session II, which was held on June 12 - June 16, 2006. There were a total of 49 students enrolled in the $3^{\text {rd }}$ and $4^{\text {th }}$ grade classes in this summer session. Participants for this study were recruited by mailing an invitation letter and consent form to parents of the $3^{\text {rd }}$ and $4^{\text {th }}$ grade GERI students. Students who returned signed parental forms were eligible to volunteer for this study; these students signed an assent form prior to participating. 
Eighteen (18) GERI students volunteered to participate in this research study. Table 1 shows the classes in which these students were interviewed. Eight students were enrolled in two classes, as described in the notes for Table 1. The study sample included 12 males and 6 females; 17 Caucasian students and 1 Hispanic student. All of the students had just completed either $3^{\text {rd }}$ or $4^{\text {th }}$ grade in the previous academic year, and they ranged from 8 to 10 years old.

Table 1. Number of Participants in GERI Super Summer Classes

\begin{tabular}{|c|l|c|}
\hline \multicolumn{2}{|c|}{ GERI Super Summer Class } & $\begin{array}{c}c \\
\text { Participants } \\
\text { Interviewed in Class }\end{array}$ \\
\hline \multirow{3}{*}{$\begin{array}{c}\text { Morning } \\
\text { Classes }\end{array}$} & Building Bridges $^{\mathrm{a}}$ & 4 \\
\cline { 2 - 3 } & Be an Engineer $^{\mathrm{b}}$ & 5 \\
\cline { 2 - 3 } & Experimental Chemistry $^{\mathrm{c}}$ & 4 \\
\hline \multirow{3}{*}{$\begin{array}{c}\text { Afternoon } \\
\text { Classes }\end{array}$} & 3-D Modeling and Computer Animation & 1 \\
\cline { 2 - 3 } & Claymation: Stop Motion Animation $^{\text {Junior Astronaut }}{ }^{\mathrm{d}}$ & 0 \\
\cline { 2 - 3 } & Physics with Toys $^{2}$ & 2 \\
\cline { 2 - 3 } & Mini-Med School & 0 \\
\hline & Total Number of Participants & $\mathbf{1 8}$ \\
\hline
\end{tabular}

a. Two students also enrolled in Physics with Toys and one student enrolled in Junior Astronauts

b. Two students also enrolled in 3-D Modeling

c. One student also enrolled in Physics with Toys and one student enrolled in Mini-Med School

d. One student also enrolled in Experimental Chemistry

\section{Research Methodology}

This study applies qualitative research methods to deeply understand the perspectives of the participants. ${ }^{13}$ The methodological framework being used for this study is constructivism. The foundational questions of this framework include the following: "How have the people in this setting constructed reality?" "What are their reported perceptions, 'truths,' explanations, beliefs, and worldview?" "What are the consequences of their constructions for their behaviors and for those with whom they interact?"(pg. 96) ${ }^{13}$ Constructivists believe that humans interpret and construct their worlds, and for this reason, the physical world differs from the human world. The constructivist framework was chosen for this study as the focus is on students' perceptions of engineers, how they learned about engineering, and if they could envision themselves as engineers in the future.

Data were collected either during class time or during the hour-long student break between the morning and afternoon classes. Data were collected on the first day of class, except for 3 students who agreed to participate on the second and third day of class. Data sources for each student include: a student background questionnaire, a drawing of an engineer doing engineering work, and an individual interview. The use of multiple forms of representation, including visual, written, and spoken forms, is beneficial for revealing more information about people's conceptions. ${ }^{14}$ The background questionnaire included questions regarding (1) demographic information, (2) personal knowledge of an engineer and if so, relation to student; and (3) student's prior participation in engineering classes/programs. Students were instructed to draw 
an engineer doing engineering work. For the drawing activity, students were given a sheet of blank paper, a box of colored markers, and one pencil. Students were allowed to draw freely until they were done with their drawings. The students also wrote written descriptions of their drawings on the questionnaire. The questionnaires and the drawings were collected from the students and used in follow-up individual interviews. During the semi-structured interview, students described their drawing, anything else they knew about engineers, how they learned about engineering, and whether they would be interested in being an engineer one day. The interview allowed students to describe their drawings in their own words and explain their perspectives. The interviewer also asked students questions about specific drawing components.

Data analysis for this study was conducted using inductive data analysis, whereby patterns and themes emerged from the data. Three researchers (i.e. the lead researcher and two peer debriefers) conducted the data analysis for this study. These researchers applied content analysis to the student drawings and transcripts. Content analysis is broadly defined as "any technique for making inferences by objectively and systematically identifying specified characteristics of messages." 15 Applying content analysis was an iterative process that entailed the identification of variables, the development of a coding scheme, and the use of the coding scheme to classify data. In order to select variables, researchers individually read and reread the interview transcripts and questionnaire responses and reviewed the drawings several times to become familiar with the data. Researchers then reread and recorded their impressions of the data to highlight important ideas emerging from the data. Collectively, researchers created descriptive categories to describe the data. Once codes were created, the researchers developed a coding scheme, including the name and definition of each code. Researchers then independently coded the entire data set using the coding scheme. After this, the researchers met and compared results and discussed any disagreements. As a group, the researchers decided on the final coding for the drawings and interviews. ${ }^{16}$

This study applied several methods to improve the trustworthiness of the research. Multiple researchers analyzed the data during data analysis to improve the validity of the findings. ${ }^{17}$ These researchers documented their own personal perspectives and strived to fairly represent the students' perspectives. During the data analysis, the researchers attempted to focus on the students' perspectives. In addition, triangulation of data was used to learn from multiple student perspectives. Triangulation occurred across the three different data sources: student questionnaires, drawings, and interviews. This allows researchers to better understand the beliefs of the participants.

$\underline{\text { Researchers. }}$ The authors of this paper include an engineering education graduate student, an engineering education faculty member, and an education faculty member. These three researchers were involved in designing the research study and creating the interview protocol. The engineering education graduate student administered the questionnaires and drawings and conducted the individual student interviews. The graduate student worked with two former K-12 educators and current education graduate students to conduct the coding for the study. Conducting data analysis with researchers in different areas was beneficial for looking at different perspectives while discussing the students' responses. 


\section{Results}

The following results briefly describe the reported backgrounds of the students. Next, findings describing students' drawings, written responses to questionnaire items, and interview responses are divided into what engineers do, what engineers use, and what engineers consider. The categories shown are ones in which multiple students reported such responses. Finally, there are several sections detailing findings about the research participants.

Student Background. Of the 18 participants in the study, four students reported that they had participated in an engineer classes or program prior to this study. These classes included two classes held at Purdue University, one of these classes was a GERI chemistry class, which is not actually considered an engineering class. Another student could not remember the name of the engineering class. Ten students reported that they knew an engineer. The relationship of the engineers to the students included fathers, mothers, grandfathers, and a family friend.

What Engineers Do. GERI students provided various descriptions of what engineers do. According to the students: engineers do the following: "design," "fix," "build," "test," "work on or invent things". The phrase "work on" was used to describe engineers either physically working on an object or working in front of a computer. The students also drew pictures of several engineers working as physical laborers. Table 2 shows the number of responses in each category and provides an example of student responses to the different types of engineering actions. Sample student drawings of an engineer fixing a car and an engineer working on a machine are shown in Figure 1.

Table 2. Actions of engineers represented in student drawings.

\begin{tabular}{|l|c|l|}
\hline Actions of the Engineers & $\begin{array}{c}\text { Number of } \\
\text { Participants }\end{array}$ & Example Participant Response \\
\hline Design/Plan & 5 & $\begin{array}{l}\text { Well I think an engineer basically is someone who } \\
\text { designs things...And basically what I drew is an } \\
\text { engineer planning and drawing. } \\
\text { (Student J) }\end{array}$ \\
\hline Build/make & 4 & It's an engineer building a house. (Student D) \\
\hline Work on & 3 & $\begin{array}{l}\text { It's a picture of a guy working on some rocket. } \\
\text { (Student R) }\end{array}$ \\
\hline Fix & 3 & $\begin{array}{l}\text { Um the car, it stopped working and they put it in a } \\
\text { shop and he's fixing it and he can't find what's wrong, } \\
\text { so he's frowning. (Student K) }\end{array}$ \\
\hline Invent, discover: & 3 & $\begin{array}{l}\text { Well I know that engineers, they are sort of like } \\
\text { inventors, basically another name for inventors. } \\
\text { (Student G) }\end{array}$ \\
\hline Test/Experiment/Record data & 7 & $\begin{array}{l}\text { And then he's recording data. (Student N) } \\
\text { machine. (Student P) }\end{array}$ \\
\hline Physical laborers & 3 ang ing showing an enginer working on a \\
\hline
\end{tabular}




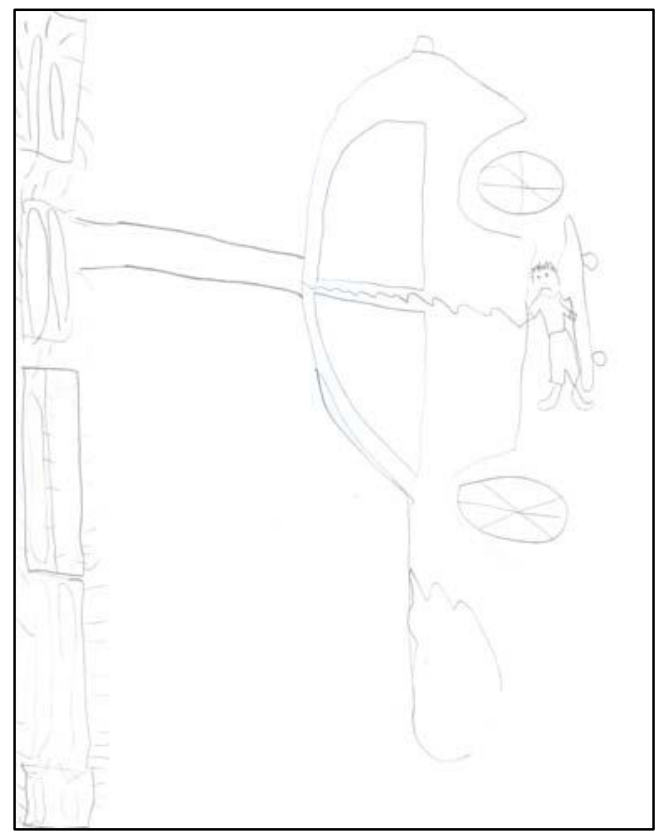

(a)

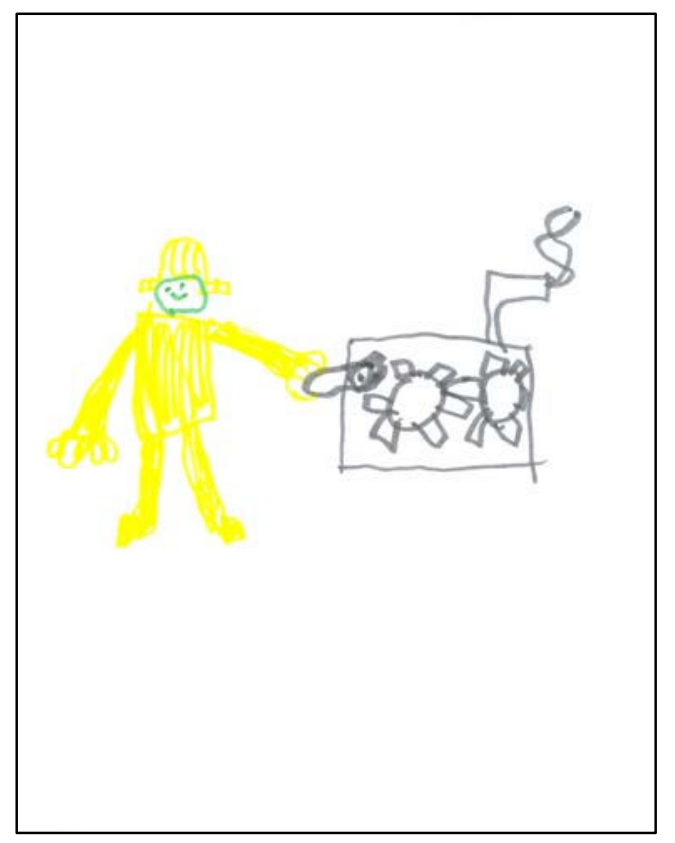

(b)

Figure 1. Sample student drawings done by Student $K$ (a) and Student $P$ (b) showing actions of engineers.

What Engineers Use. Engineers shown in the drawings used different types of items to do their work. Table 3 describes categories of items drawn and provides sample student responses for each category. Some students drew engineers wearing protective gear to ensure their personal safety while completing their work. These engineers were wearing items such as hard hats, masks, or goggles. Engineers were using, and in some cases creating, models, blueprints, and plans. Several students showed engineers with computers; most of these engineers were using the computers to do their engineering work. One of the students stated that the engineer had a computer in his office, but did not describe how the engineer was using the computer. Figure 2 shows an engineer mixing chemicals while wearing protective gear and an engineer working on a computer.

Table 3. Items used by engineers in student drawings

\begin{tabular}{|l|c|l|}
\hline Items Used by Engineers & $\begin{array}{c}\text { Number of } \\
\text { Participants }\end{array}$ & Example Participant Response \\
\hline Items for personal safety & 6 & $\begin{array}{l}\text { That's a little helmet to protect him. These are his } \\
\text { goggles. (Student Q) }\end{array}$ \\
\hline Models, blueprints, plans & 4 & $\begin{array}{l}\text { Idrew a woman who's an engineer and she's at a } \\
\text { meeting and she's talking about the blueprints of that } \\
\text { building, tallest building. (Student L) }\end{array}$ \\
\hline Computers & 5 & $\begin{array}{l}\text { Um the lady is working on the computer, like my dad } \\
\text { does...(Student O) }\end{array}$ \\
\hline
\end{tabular}




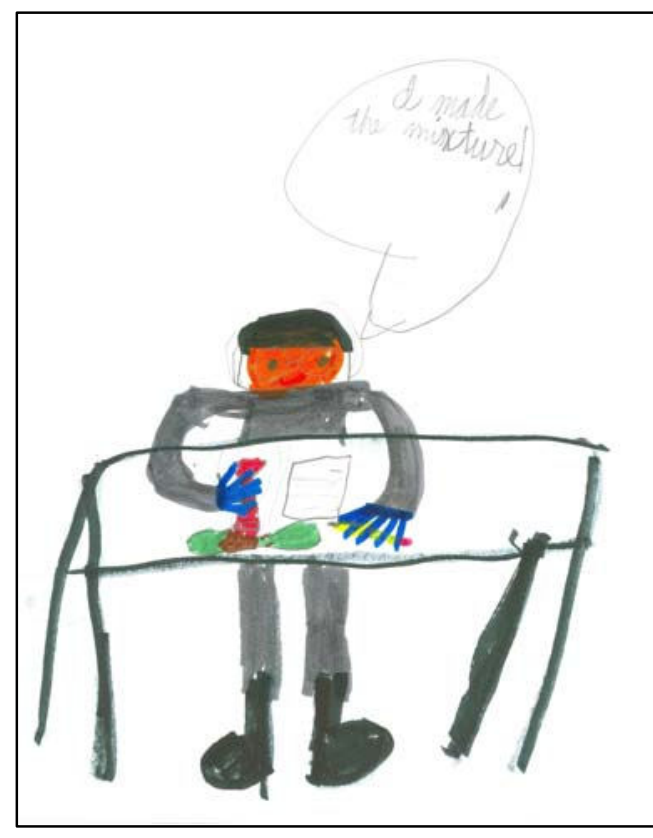

(a)

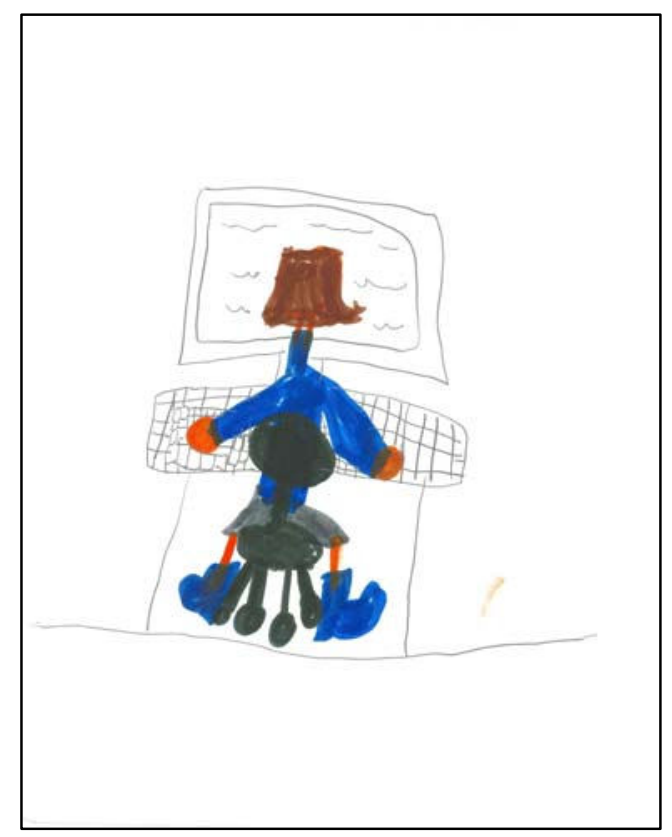

(b)

Figure 2. Sample student drawings by Student $Q$ (a) and Student $O$ (b) showing items engineers use to do their work.

What Engineers Consider. During the interview, several students described considerations engineers have while doing engineering work; these types of responses are summarized in Table 4. One of the questions asked during the interviews to probe students about their drawing was: what might the engineer be thinking while doing what they were doing? Most students talked about the types of things engineers consider when asked this question. A few students discussed considerations at other times in the interview. Two types of considerations were (1) drivers for engineering work and (2) whether the engineering product or service works or meets the expectations of the engineer. Drivers for the engineering work included things such as helping people (healing, safety) and earning money. In terms of expectations, students either had questions about whether or not something was working well or showed engineers who were getting what they expected. Student quotes in Table 4 that accompany Figure 3 refer to an engineer thinking about the work he does "for the world" and an engineer questioning if "this" meets personal expectations. Another example of meeting expectations is Student Q in Figure 2 who drew a "happy" engineer who made the mixture he wanted to make.

Table 4. Considerations of the engineers in student drawings

\begin{tabular}{|l|c|l|}
\hline Considerations & $\begin{array}{c}\text { Number of } \\
\text { Participants }\end{array}$ & Example Participant Response \\
\hline Drivers & 6 & $\begin{array}{l}\text { Probably thinking that he's doing something good } \\
\text { for the world. (Student R) }\end{array}$ \\
\hline Does it meet expectations? & 5 & $\begin{array}{l}\text { Is this what I wanted, is that what I wanted. Did I } \\
\text { do this right? Did I do that right? (Student E) }\end{array}$ \\
\hline
\end{tabular}




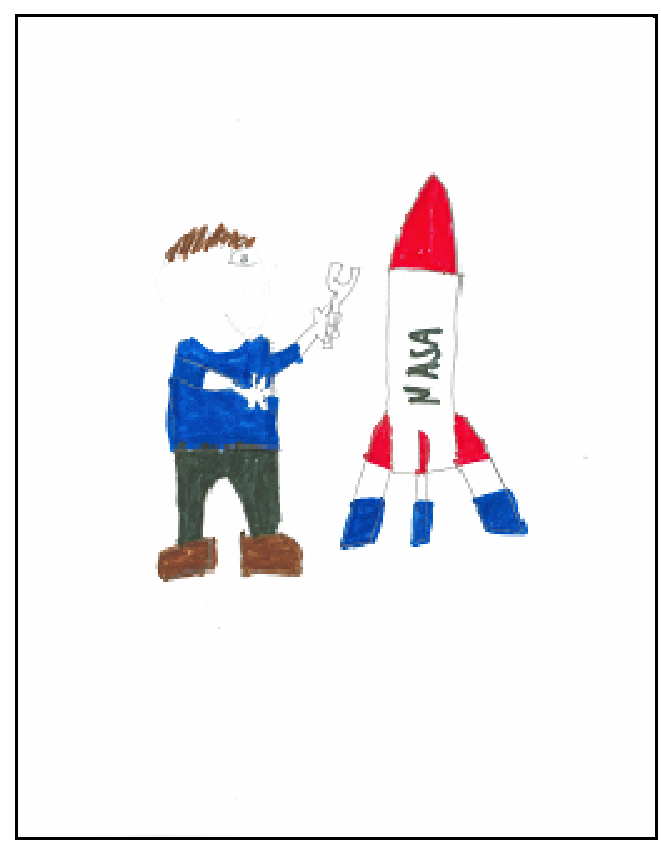

(a)

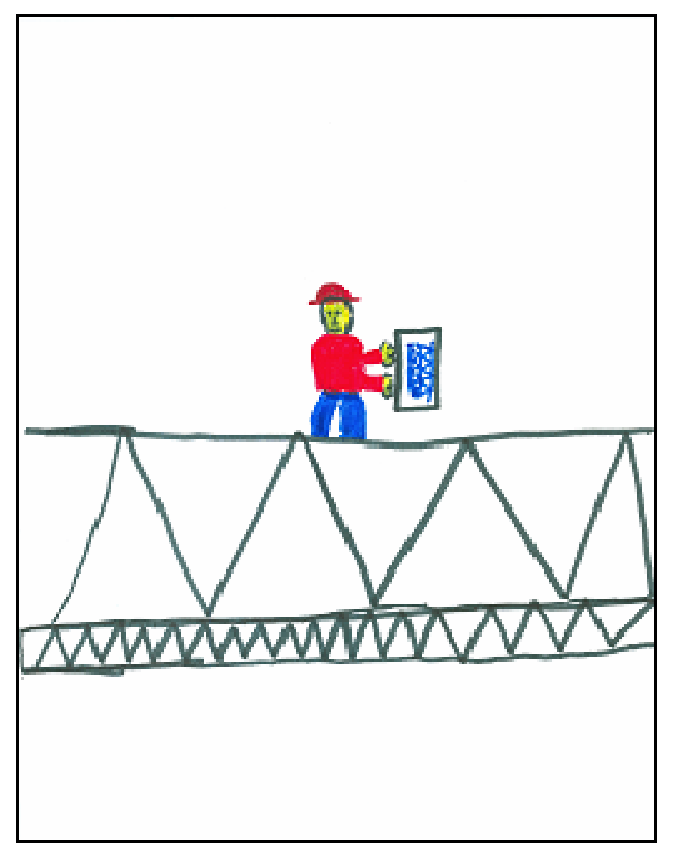

(b)

Figure 3. Sample student drawings by Student R (a) and Student E (b) showing what engineers consider.

Students - Learning about Engineering. Students reported, through interviews, where they learned about engineering prior to attending the program. These sources and the number of participants in each response category are detailed in Table 5 . The family members included parents, grandparents, and one sibling. The family members included engineers and people who were not engineers. Television shows included shows on the Discovery Channel. One student described an experience where she met an engineer in person. In this incident, her mom's car broke down and they went to a shop where an "engineer" fixed her car.

Table 5. How Students Learned about Engineering

\begin{tabular}{|l|c|}
\hline Category & $\begin{array}{c}\text { Number of } \\
\text { Participants }\end{array}$ \\
\hline \hline Family member & 11 \\
\hline Books & 5 \\
\hline TV or movies & 5 \\
\hline Classroom at school & 3 \\
\hline Engineering program & 1 \\
\hline Study on own & 1 \\
\hline Play with a friend & 1 \\
\hline Internet & 1 \\
\hline Personal experience & 1 \\
\hline Don't know & 1 \\
\hline
\end{tabular}

Students - Interest in Engineering. Student interest in becoming an engineer one day varied: 9 students said yes, 6 students said maybe, and 3 students were not interested in becoming engineers. Students interested in becoming engineers reported reasons such as enjoying 
inventing things, wanting to build a roller coaster, or seeing the things they designed actually used in the future. One student specifically said he wanted to become a chemical engineer; his grandfather was a chemical engineer. Students not interested in becoming engineers said that there were other things they wanted to do.

Students - Other Findings. Two children discussed their awareness of a common misconception about engineers. These students referred to the conception that engineers drive trains and stated:

- "Some people think that they, well an engineer, they think train or um but they are not like that.....well it is an engineer, but it's a different kind of engineer."

- "When I was little it probably would be like a person who drives a train, but now I think there are lots of different types of engineers. Like mechanical, electrical, stuff like that."

Another finding was that drawings and interviews of students who knew engineers were influenced by the engineers. Generally, students who knew engineers drew that engineer or referred to those engineers during their follow-up interview. For example, one girl has a father who is an engineer and uses computers, and she drew a lady working at a computer like her father.

\section{Discussion}

The purpose of this study was to examine $3^{\text {rd }}$ and $4^{\text {th }}$ grade GERI students' perceptions of engineers. The results showed that students drew and described what engineers do in various ways. Some students had common misconceptions about engineers, ${ }^{8,9}$ while others reported that engineers design or plan. Two students discussed their awareness of a common misconception about engineers. Students also drew engineers using personal safety items, computers, and models, blueprints, or plans. Students also described things engineers considered while doing engineering work such as whether their product or experiment was working and the drivers for their work. Students learned about engineering from a variety of sources and had varying interest in becoming an engineer. Approximately $55 \%$ of the participants in this study knew an engineer, and less than $30 \%$ students reported taking engineering-related classes prior to this study.

The context of this study makes the findings unique because the students are enrolled in a gifted outreach program which is held at a largely engineering institution. Children in such communities or with access to programs in such areas may have greater access to engineers, including parents, other engineers, and engineering students, than the overall population of $3^{\text {rd }}$ and $4^{\text {th }}$ grade students. Some GERI students reported learning about engineering from parents and from programs held at Purdue University. For example, one student referred to engineering in terms of an annual Purdue University engineering design contest. It would be easy to believe that students with such exposure would have more accurate conceptions than students who do not have access to an engineering role model. The results of the study show that there were students who described engineers as people who design. However there were students, including students who reported knowing an engineer, with less accurate conceptions. 
It was interesting to hear such young students describe the idea that engineers design and plan. One of the students, who said an engineer was designing, did not know what the engineer was designing. For students who know an engineer, they may or may not have asked the engineer many questions about what they do or about all the different types of things they do. The results indicate that these children are learning a new language and have had limited experience with developing this language into useable knowledge and critical understanding of the field. Some students may need to build on their understanding of and ability to describe engineering design. This will require more than telling students what engineers do. According to the National Research Council,

Simply telling students what scientists have discovered, for example, is not sufficient to support change in their existing preconceptions about important scientific phenomena. Similarly, simply asking students to follow the steps of "the scientific method" is not sufficient to help them develop the knowledge, skills, and attitudes that will enable them to understand what it means to "do science" and participate in a larger scientific community. ${ }^{18}$

In engineering classes for K-12 students, engaging students in design can provide students with exposure to the types of things engineers design. Engaging in design can also help students gain an understanding of what it means to design and the types of things an engineer might consider while designing.

Learning about students' conceptions about engineering is important for engineering education. "Instruction in any subject matter that does not explicitly address students' everyday conceptions typically fails to help them refine or replace these conceptions with others that are scientifically more accurate."19 For example, addressing personal experiences which have formed students' conceptions about who engineers are and what they do is important. Personal experiences with engineering were represented in many of the children's drawings. One student had interacted with a car mechanic, and called this person an engineer. This shows an example of a student who developed a common misconception about engineers from a personal experience. The students' interest in engineering was based on this misconception - she reported that she would not be interested in being an engineer in the future, and that she does not like to get dirty.

This research is limited by the following factors: 1) the student population is not representative of typical $3^{\text {rd }}$ and $4^{\text {th }}$ graders; and 2) abbreviated interviews that provided only partial information about students' beliefs about engineering.

\section{Conclusion}

This study provides insight on children's perceptions about engineers for children enrolled in several classes in a gifted outreach program. These findings have implications for educators developing K-12 engineering education classes. At the beginning of class, it is important to assess what the students understand about engineering and what their past experiences with engineers have been. A recommendation is to ask students what they know about engineers and to have them think about how they learned it. This will help instructors to understand children's backgrounds and understanding of engineering and to identify misconceptions. When students do have access to, or can be provided access to, practicing engineers, it would be beneficial to 
have students ask engineers specific questions about what they do. In addition, students should engage in the engineering design process. Such measures will help students better understand what engineers do while they are taking an engineering class.

This research has informed the design of a current research study which focuses on the perceptions of students enrolled in only engineering outreach classes. This research focuses on students who have an interest in engineering at a young age. Their perceptions are being studied prior to engineering instruction and after engineering instruction. During interviews, students are being asked to explain how they learned about engineering. Students are also being asked to explain their understanding of terms such as design, if they use such a term to describe what engineers do. This research will add to the literature on children's conceptions of engineers and the nature of engineering.

\section{Acknowledgements}

The authors would like to acknowledge Purdue University graduate students, Matt Lambert and Daphne Duncan, for serving as peer reviewers for this research.

\section{Bibliography}

1. National Academies Committee on Science, Engineering, and Public Policy. (2006). Rising Above The Gathering Storm: Energizing and Employing America for a Brighter Economic Future Washington, D. C.: National Academies Press. pg.ES-2.

2. Jackson, S. A. (2002). The Quiet Crisis: Falling Short of Producing American Scientific and Technical Talent [Electronic Version]. Retrieved October 23, 2006.

3. National Science Board. (2004). Science and Engineering Indicators 2004 Two volumes. Arlington, VA: National Science Foundation (volume 1, NSB 04-1; volume 2, NSB 04-1A).

4. Pearson, G. (2004). Collaboration conundrum (Editorial). Journal of Technology Education, 15(2), 66-76.

5. National Academies of Engineering. (2004). Ninth Annual Symposium on Frontiers of Engineering. Washington, D.C.: National Academy of Science.

6. Pearson, G., \& Young, T. (2002). Technically speaking: Why all Americans need to know more about technology. Washington, DC: National Academy Press.

7. Douglas, J., Iverson, E., \& Kalyandurg, C. (2004). Engineering in the K-12 classroom: An analysis of current practices \& guidelines for the future. Retrieved April 15, 2006, from $\mathrm{http} / / / \mathrm{www} . e n g i n e e r i n g k 12 . o r g /$ educators/taking_a_closer_look/reports.htm

8. Thompson, S., \& Lyons, J. A. (2005). A study examining change in underrepresented student views of engineering as a result of working with engineers in the elementary classroom. Paper presented at the ASEE Annual Conference and Exposition.

9. Knight, M., \& Cunningham, C. (2004). Draw an engineer test (DAET): Development of a tool to investigate students' ideas about engineers and engineering. Paper presented at the ASEE Annual Conference and Exposition.

10. Cunningham, C., Lachapelle, C., \& Lindgren-Streicher. (2005). Assessing elementary school students' conceptions of engineering and technology. Paper presented at the ASEE Annual Conference and Exposition.

11. Lyons, J., \& Thompson, S. (2006). Investigating the long-term impact of an engineering-based GK-12 program on students' perceptions of engineering. Paper presented at the ASEE Annual Conference and Exposition.

12. GERI. (2006). Gifted Education Resource Institute. Retrieved August 18, 2006, from http://geri.education.purdue.edu 
13. Patton, M. Q. (2002). Qualitative Research \& Evaluation Methods (3rd ed.). Thousand Oaks, CA: Sage Publications.

14. Douglas, K. B. (1998). Seeing as well as hearing: Responses to the use of an alternative form of data representation in a study of students' environmental perceptions. Paper presented at the Annual Meeting of the Association for the Study of Higher Education.

15. Holsti, O. R. (1969). Content Analysis for the Social Sciences and Humanities. Reading, MA: Addison-Wesley Publishing Company, Inc., pg. 14.

16. Neuendorf, K. (2002). The Content Analysis Guidebook. Thousand Oaks, CA: Sage Publications.

17. McMillan, J. H., \& Schumacher, S. (2001). Research in Education: A Conceptual Introduction (5th ed.). New York, NY: Addison Wesley Longman, Inc.

18. National Research Council. (2005). How students learn: history, mathematics, and science in the classroom. Committee on how people learn, A targeted report for teachers, M.S. Donovan and J.D. Bransford, Editors. Division of Behavioral and Social Sciences and Education. Washington, DC: The National Academies Press. pg. 398.

19. ibid. pg. 1. 